\title{
The Construction of The Role of Women in Indonesia Novels in the 1920s
}

\author{
Ade Putra, Yasnur Asri, Yenni Hayati \\ Universitas Negeri Padang \\ adeputra172@gmail.com
}

\begin{abstract}
This study aimed to describe the construction of the role of women in the novels of Indonesia in the 1920s. The data in study were figure of speeches, speeches of the narrator, description of the behavior of character. Issue in this study is about the construction role of women contained in the novels of Indonesia in the 1920s. This study used four novels as the sources; Sitti Nurbaya by Marah Rusli, Azab dan Sengsara by Merari Siregar, Kehilangan Mestika by Hamidah, and Manusia Bebas by Suwarsih Djojopuspito. This study used a qualitative content analysis techniques. Data validation was done by triangulation techniques, which checks the validity of data that take advantage of something else outside of the data. Based on the results, we can conclude the role of women in the novels Indonesia in the 1920s is divided into two parts. First, the domestic role of women in the world that includes the role as a child, the role of wife and motherhood. Second, the role of the public world that includes the role of education and role in the public organization.
\end{abstract}

Keywords--gender construction; Indonesian women; and 1920s novels

\section{INTRODUCTION}

The position of women in the social environment has been constructed for long ago. This construction as a friend put women behind men whose lives revolve around the issue only wells, mattresses and kitchen. (Saputra, 2011, p. 18). The existence of this construction cannot disconnect from patriarchal ideology. Patriarchy is an ideology that considers man as controlling anything, and women as second-class in society. (Asri, 2014, p. 447; Wiyatmi, 2010, p. 202). In line with Andari, 2011, p. 313; Dwipayana, 2017, p. 39), states that the patriarchy is a system in the social structure and in practice males dominate, oppress and exploit women. Women are still considered to be the second class which is often referred to as "second class citizens" whose existence is not taken into consideration. The implications of the concept and the common sense of positioning is not balanced has become a force in the separation of sectors of life into the sector "domestic" and the sector "public", in which women are considered those that take part in the domestic sector while men are placed in the public sector. The ideology of this kind has been endorsed by various institutions and social agencies, and then becoming a social fact about the status and the role played by women (Hermawati, 2007, p. 21; Pranowo, 2013, p. 57; Martha, 2010, p. 225; Kurnianto, 2014, p. 30). Similarly Astuti (2008, p. 3) states that women are "residents" of the kitchen or domestic, can not think rationally and less willing to take risks, all of which have become stereotypes of women. As a result, both women and men in society in general,

The ideology of patriarchy makes women had no role in the public sphere. This is in line with the opinions Ritongga (2016, p. 14), that in a society that embraces the culture of patriarchy, women have no role to interact in public spaces. The existence of women merely complementary to the perpetuation of male power, because their rights have also been traded so that the position of women is no longer useful.Imbalance between the roles of men with the role of women cannot be separated from education obtained. Trianton $(2009$, p. 365) says that the difference in the level of education is a major factor that degrades women is slightly lower than men, which ensues is the domination of men over women in various fields of life. This is then referred to as the culture of patriarchy.

The culture of patriarchy in Indonesia in the 1920s so thick. This is evident in the tradition of seclusion and gender construction that putswomen as domestic creatures, is as a housewife. Wiyatmi $(2010$, p. 143) states seclusion is a tradition in some communities in Indonesia that requires a 12-year-old girl had to stay at home, until he gets his soul mate. He said seclution word taken from the word "horse seclusion" which means horses are kept in cages and not allowed to roam freely like any other horse. The metaphor can be accepted for their significant association between the horses who were not allowed out of the cage with a woman who was not allowed out of their home environment.

In addition to the limitations of cultural seclusion of women in education is also felt. The women will learn in school is also constrained by a number of schools are still limited, as not everything can be entered by women. In accordance with the historical social context of the time, the number of schools and Indonesian people is still very little education, especially of women. This is consistent with that proposed by (Wiyatmi, 2010, p.144) based on the results of research conducted by Mahlenfeld were published in the daily de Locomotief the early twentieth century in Java, the average of 1000 people only 15 people who can read and write. If women counted, the total to 16.

Novel Sitti Nurbaya, Azab dan Sengsara, Kehilangan Mestika, and Manusia Bebas provide criticism of the patriarchal culture that limits the role of women in education and provide space for women to work in the public domain. Phenomena about the tradition of seclusion and gender construction that puts women as domestic creatures, 
which act as a housewife, already at critics by Indonesian authors in fiction, like Marah Rusli in the novel Sitti Nurbaya and Merari Siregar in the novel Azab dan Sengsara. The phenomenon is also discussed by Suryaman et al. (2012), which explains that the novel written by authors who have gained a modern education, began to criticize the negative sides of traditional customs that apply strictly, especially in Batak and Minangkabau society in terms of educational discrimination against girls and forced marriages. Based on this background, the researchers interested in studying how the construction of the role of women in the Indonesian novels 1920s in terms of the theory of liberal feminism. This is caused by liberal feminism trying to fight for women achieving equal legal rights and social and political. Being able to bring equality for women in all public institutions to expand knowledge creation for women to issues concerning women are no longer ignored. Fakih (2008) the basic assumptions of liberal feminism grounded in the notion that freedom and equality is rooted in rationality and separation between private and public world.

\section{METHODS}

This study used qualitative content analysis techniques. Sources of data in this study there were four novels are novels Sitti Nurbaya by Marah Rusli, Azab dan Sengsara by Merari Siregar, Kehilangan Mestika by Hamidah, and Manusia Bebas by Suwarsih Djojopuspito. The research data were figure of speeches, speeches of the narrator, description of the behavior issues in this study on the construction of the role of women contained in the novel. Collecting data in this study was conducted in three phases, read and understand the novel. Second, identify the line that says the role of women in the novel construction of the novel. Third, inventory data by using the format of the data inventory. The data in this study, is analyzed through four stages. First, describing the data obtained from these novels. Second, analyze the data collected from these novels. Third, Interpret data collected from these novels. Fourth, conclude and write research reports.

Fakih (2008) stated that the image of women in the domestic sector, women contribute as wives, as mothers, and as family members who behave well. In addition to the role of women in the domestic sector is also contained in the public sector, such as the religious sector, education, economics, and politics. The respective roles of social attitudes will bring consequences, associated with one another. As a wife, for example, as women love their husbands, to motivate, and as assistant in her husband's life.

Women in the family can play a role as a wife. That role is in accordance with the role that the privilege of women. The role of women in a family can also serve as a mother. The role of the usual one woman gave birth and caring for their children with love and sincere affection as the responsibility of the authority in order to become a complete woman (Fakih, 2008).

The role of women is reflected in the education sector, not only in families to educate their children, but in the public sector with gentle, women are able to transform into educators have good quality and trustworthy (Fakih, 2008).

Arivia (2006) stated that women's role is only to manage chores like cleaning the house, washing clothes, cooking, taking care of the kids and serve her husband.

Asri (2014a, p. 449; 2014b, p. 190), divide the role of women into 5 namely (1) wife, (2) the mother, educators, builders of the younger generation, (3) the financial manager, (4) gain money for the family's needs (to help her husband), (5) members of society, especially women's organizations and social organizations.

Based on some of the above opinion, the researchers divided the role of women in general into two: (1) the role of women in the domestic world that includes the role of women as children, the role of women as wives and women's roles as mothers. (2) the role of women in the public sphere that includes the role of women in education and the role of women in the organization.

In this study, researchers found 76 data on the construction of the role of women in the novels of Indonesia in the 1920s. 
Table 1. Construction of the role of women in the novels of Indonesia in the 1920s.

\begin{tabular}{|c|c|c|c|c|c|c|c|}
\hline \multirow[t]{3}{*}{ novel } & \multirow{3}{*}{ author } & \multicolumn{5}{|c|}{ role of women } & \multirow{3}{*}{$\begin{array}{c}\text { Num } \\
\text { ber } \\
\text { of } \\
\text { Data }\end{array}$} \\
\hline & & \multicolumn{3}{|c|}{ Domestic } & \multicolumn{2}{|c|}{ Public } & \\
\hline & & $\begin{array}{l}\text { Role as } \\
\text { a child }\end{array}$ & $\begin{array}{l}\text { Role as } \\
\text { a wife }\end{array}$ & $\begin{array}{l}\text { Motherho } \\
\text { od }\end{array}$ & $\begin{array}{c}\text { Role in } \\
\text { education }\end{array}$ & $\begin{array}{l}\text { Role in the } \\
\text { organization }\end{array}$ & \\
\hline $\begin{array}{c}\text { Sitti } \\
\text { Nurba- } \\
\text { ya }\end{array}$ & $\begin{array}{c}\text { Marah } \\
\text { Rusli }\end{array}$ & 9 & 3 & 2 & - & - & 14 \\
\hline $\begin{array}{l}\text { Azab } \\
\text { dan } \\
\text { Sengg- } \\
\text { sara }\end{array}$ & $\begin{array}{l}\text { Merari } \\
\text { Siregar }\end{array}$ & 9 & 1 & 1 & - & - & 11 \\
\hline $\begin{array}{c}\text { Kehila } \\
\text { ngan } \\
\text { Mesti- } \\
\text { ka } \\
\end{array}$ & Hamidah & 7 & 1 & 1 & 4 & 3 & 16 \\
\hline $\begin{array}{c}\text { Manu- } \\
\text { sia } \\
\text { bebas }\end{array}$ & $\begin{array}{c}\text { Suwarsih } \\
\text { Djojopus } \\
\text { pito }\end{array}$ & 2 & 21 & 6 & 3 & 3 & 35 \\
\hline & & & & & & & 76 \\
\hline
\end{tabular}

\section{FINDING AND DISCUSSION}

The data in this study are located in four novels. Two novels wrote by male author and two more novels are female's works. Novels by male authors of this study are novel Sitti Nurbaya by Marah Rusli and Azab dan Sengsara by Merari Siregar. Sitti Nurbaya has social background of Minangkabau; Azab dan Sengsara provide Batak social background. Both of these novels have in common as follows:.

\section{Equally as criticizing the tradition of seclusion}

This is found in the Sitti Nurbaya novel, hereinafter referred to as SN.

"The second things that caused us weaker and less perspicacious than for the men are the maintenance, employment and our obligation. On our maintenance, since we started good at running, until the age of seven years we can be said to be little free; may take a walk to and fro, while we are heartened, when we feel free. Then it until to our old age, our lives is from the house to the kitchen and from the kitchen were restored to home. If the seven-eight years, began caged as birds, not looking at the sky and the earth, so nobody knows what is happening around us. While clothing and food are not ignored, moreover the will and preferences of the wish. Meanwhile we are told to learn to cook, sew, keeping the household, the whole jobs that cannot add strength and sharpens the mind.(SN:204)

The above quotation is the role of women as children characterized by causality. The role of the child has relation with parents. Sitti Nurbaya is a child obedient to their parents and seclusion tradition prevailing in society as well as he knows his duty as a son. But he had the forethought is why women are weak and less sharp than men. Thought Sitti Nurbaya just a new form of ideas about equality between men and women, but Sitti Nurbaya still knows his duty as a daughter in carrying out his duties.

The same thing is also found in the novel Azab dan Senggsara, hereinafter referred to as ADS.

You're happy to look at the male, who is higher than women? "Indeed," said Mariamin immediately. If I am a man, of course I'm strong work as a man, I am glad, because in my younger days I may someday go there-here, go to the country people migrated to the Deli will be looking for work. Differ to our women. Women should stay at home, should not be often out-outside, if the body is large (ADS:38).

The above quotation is the role of women as children characterized by causality. The role of the child has relation with parents. As a child, Mariamin is obedient and submissive to parents. Because adherence to the parent. Mariamin follows the rule that women should stay at home following the tradition of seclusion.

\section{The necessity of being a wife}

This is found in the Sitti Nurbaya novel, (hereinafter referred to as SN). 
If you are willing to become the wife of Datuk Meringgih, save me, do not go to prison and certainly not going to sell our house and land. However, if you are not willing to, I and all of us are still there, will fall into it (SN: 148).

The above quotation is the role of women as children characterized by causality, as the role of the child in touch with the parents, as a child Sitti Nurbaya listening to the advice of his father. Due to the advice of his father, Sitti must make a choice between saving his father from getting into debt Datuk Meringgih a way to marry her or seen her father go to jail for not being able to pay off his debts to Datuk Meringgih.

The same thing is also found in the novel Azab dan Senggsara, (hereinafter referred to as ADS).

Then she married a young man from Mulberry, young people who are not familiar, the young man that is not loved, mate did not she like (ADS: 145).

The above quotation is the role of women as children characterized by causality. The role of the child has relation to parents. As a child, Mariamin obey their parents in making decisions. Because compliance was Mariamin accept his marriage to Kasibun namely the youth loved nothing, mate did not she like.

\section{Being a disobey wife to the husband}

This is found in the Sitti Nurbaya novel, (hereinafter referred to as SN).

Hearing this poem, Nurbaya cannot restrain by his heart again, then hugged and kissed his cheek Samsul. Replied by Samsul kiss hug her boyfriend with passion. In the embrace and kiss, suddenly a voice came from behind Datuk Meringgih say so, "why, then so hard your hearts will go home and not going to turn me. Instead of going to keep your father, as you say. Just going to have fun with your lover (SN: 195).

The above quotation is the role of women as wives characterized by causality. The role of women as wives relates to a husband. As the wife Sitti Nurbaya is not a dutiful wife to her husband. This is evidenced by the attitude Sitti Nurbaya which remained in contact with her boyfriend Samsul Bahri hated by her husband Datuk Meringgih.

The same thing is also found in the novel Azab dan Senggsara, hereinafter referred to as ADS.

Mariamin then went to the kitchen. So he brought three cups of coffee as well as pastries slightly and placed before Aminuddin (ADS: 156).

The above quotation is the role of women as wives characterized by causality. The role of women as wives relates to a husband. As the wife, Mariamin is not a dutiful wife to her husband. Kasibun not like Aminnudin a former lover, but Mariamin still receive Aminnudin come pay a visit put the coffee and pastries, though she knew that her husband does not like Aminnudin Kasibun.

So we can conclude novel Sitti Nurbaya by Marah Rusli and novel Azab dan Sengsara by Merari Siregar, which is novel author male construct the role of women in the novel in the form of women obedient to their parents, women who are weak because they cannot resist the tradition of seclusion, married for i.e. forced to marry someone she did not love, being disobedient wife to the husband for marrying without the basis of love, and to be a woman who only work in the domestic sector without touching the public sector.

Novel women authors in this study is novel Kehilangan Mestika by Hamidah, and novel Manusia Bebas bySuwarsih Djojopuspito. These two novels into equally have in common is equally the theme of the influx of women from the domestic sphere into the public sphere.

This is found in the Kehilangan Mestika novel, hereinafter referred to as KM.

Because in my country, I'm the first who once opened the door for girls, then various diatribe that come to the ears of my family. People of my country at that time was still too stupid and old-fashioned. Do not know them to distinguish which is said to customs and which is also the religion. (KM:18)

The above quotation is the role of women in education is characterized by the presence of a causal relationship. The role of women in education related to the public. In the seclusion Islands community is a tradition that runs for a long time. Tradition curb seclusion of women, make women does not mean, as it Hamidah protest tradition of this seclusion. Because of the relationship with the community is asymmetric or not harmonious. In protest of Hamida ie he founded a school in Palembang. Because of this, the various kinds of insults that come to the family of Hamidah.

The same thing is also found in the novel Manusia Bebas, hereinafter referred to as MB

Congress of Indonesian women being prepared. Marti was busy, running here, then there, looking back short notes that have been made by Kartonegoro, look in books, wrote a few sheets of paper, ripped it back and could not finish his speech (MB:196). 
The above quotation is the role of women in a society characterized by causality. The role of women in society related to the contribution in society. Marti will hold a congress of Indonesian women. Because of the busy Marti prepare speech by looking back at the records that have been made Kartonegoro short.

In the novel Kehilangan Mestika asymmetrical relationship with the community or not harmonious, Hamida did not participate with the community but she protests against the cultural seclusion, because the protest he founded a school in Palembang, Hamidah against the tradition that women cannot be construed as seclusion.

Manusia Bebas tells the struggle carried out by a number of indigenous intellectuals in the field of private education and women's organizations. Together with her husband, Sudarmo, Sulastri and his friends is the figure of young people who set up private schools (National Education) to give lessons to the public so as not to send their children in government schools. So we can conclude women authors construct the role of women in the form the entry of women from the domestic sphere to the public.

\section{CONCLUSION}

Based on research that has been done can be concluded that, in the novel Sitti Nurbaya by Marah Rusli and Azab dan Senggsara by Merari Siregar, the authors construct the role of women in the form of women obedient to their parents, women who are weak because they can not resist the tradition of seclusion, married out of necessity that marry someone she did not love, being disobedient wife to the husband for marrying without the basis of love, and to be a woman who only work in the domestic sector without touching the public sector.

Meanwhile, in the novel Kehilangan Mestika by Hamida and Manusia Bebas Suwarsih Djojopuspito authors construct the role of women in the form of the influx of women from the domestic sphere to the public sphere it is apparent from figures Hamidah, who founded the school in Palembang on the novel Kehilangan Mestika, while the novel manusia bebas by Sulastri leaders participate and become educators in schools Sudarmo which is her husband and the influx of educated women in the organization that looks at the figure of Marti, who was busy preparing for the congress of Indonesian women in the novel Manusia Bebas.

\section{References}

Andari, A. J. (2011). Analysis of structural victimization against three victims of trafficking in women and girls. Journal of Criminology Indonesia, 7 (III), 307-319.

Arivia, G. (2006). Feminism is a conscience. Jakarta: Book Publishers Compass.

Asri, Y. (2014). Women's struggle toward gender unfair: A case study in Indonesian Novel. Linguistics and Literature Studies 2 (7): 190-197.

Asri. Y. (2014). The representation of Javanese women's rejection toward patriarchy: A study of existential ideology of feminism toward Rara Mendut Novel by Y. B. Mangunwijaya. The International Journal of Social Sciences and Humanities Invention. 1 (6),446-457, ISSN: 2349-2031.

Astuti, T. M. P. (2008). The image of women in politics. Yinyang, 3 (1), 3-16.ISSN: 1907-2791.

Djojopuspito, S. (2000). Manusia Bebas. Jakarta: Djambatan.

Dwipayana, IKA (2017). The resistance of women against patriarchal hegemony in the public culture of Bali in novels Oka Rusmini. Stilistetika, 10 (VI), 37-52. ISSN 2089-8460.

Fakih, M. (2008). Gender analysis and social transformation. Yogyakarta: Student Library.

Hamidah. (2011). Kehilangan Mestika. Jakarta: Balai Pustaka. Molds 8th.

Hermawati, T. (2007). Javanese culture and gender equality. Journal of Mass Communications, 1 (1), 18-24.

Kurnianto. EA (2014). And deconstruction of female representation in the short story works Intan Paramaditha queen. Bina language scientific journals, 7 (I), 27-38.

Martha, N. U. (2010). Wife's image in the world without color novella collection of works of Mira W (a feminist literary studies). Muwazah, 2 (1), 225-234.

Merari, S. (2001). Azab dan Senggsara. Jakarta: Balai Pustaka. Molds to-23.

Pranowo, Y. (2013). Identity of women in patriarchal culture: a study of feminist Nawal el sa'adawi existentialist novel "women at the zero point". Crosses, 29 (1), 56-78.

Ritonga, DS (2016). Gender studies on the novel by Nawal El Saadawi and Sutan Alisjahbana. Arabiyat: Journal of Arabic and Kebahasaaraban Education, 3 (1), 13-31.

Rusli, M. (2016). Sitti Nurbaya. Jakarta: Balai Pustaka. Molds 48th.

Saputra, A. D. (2011). Subaltern women in postcolonial Indonesian literature. Literacy, 1 (1), 16-30.

Suryaman, et al. (2012). Indonesian literary history with a gender perspective. Yogyakarta: Leutikaprio.

Trianton, T. (2009). Gender-based education literature. Insania, 14 (2), 365-374

Wiyatmi. (2010). Construction of gender in the novel Geni Jola Abidah El-Khalieqy work. Humanities, 22 (2), 196206. 